\title{
Integrating Life Skills into Volleyball Extracurricular Activity Program
}

\author{
Rita Rohmanasari*, Amung Ma'mun, Tatang Muhtar, Risma Risma, Isna Daniyati Nursasih \\ Department of Sports Education, School of Postgraduates Studies \\ Universitas Pendidikan Indonesia \\ Bandung, Indonesia \\ *ritarohmanasari@student.upi.edu
}

\begin{abstract}
Youths participation in sports is entrusted to develop life skill and positive adolescence development. The purpose of this research was to find out of the impact of sports extracurricular to the development life skills of the senior high students. The method of this research was quasi-experimental design. The total samples were 67 students divided into 3 groups; volleyball extracurricular group treated with life skills integration to extracurricular program (henceforth; A), volleyball extracurricular group not treated (henceforth; B), and group of students not treated and not joined the extracurricular (henceforth; C). The results of the research show that: (1) There were different developments of life skills between A and B; (2) There was different developments of life skills between $\mathrm{A}$ and $\mathrm{C}$; (3) There was different developments of life skills between $B$ and C; (4) The treatment of life skills to A went effectively, between the pretest and the posttest revealed significant difference. Next, based on the gained score, the result of $A$ was doing good in life skills better than $B$. It was also better than $C$. It is concluded that integration of life skills to the extracurricular is effective enough to develop the life skills of student's high school.
\end{abstract}

Keywords—sport extracurricular; life skill; positive youth development

\section{INTRODUCTION}

In this $21^{\text {st }}$ century, it is a common thing to hear about the term globalization. The era of globalization is always followed by the information and technology development that become more sophisticated, so it raises the challenge for the historical subjects in their era. Human resource quality is an important asset for some nation or country. As well as Indonesian, the raising the quality of human resource can be a hope for Indonesia to go through and developing also compete in the demand of globalization era. The demand of labour become more complex and competitive raises negative impact for Indonesian because there is no suitable relevance and education output that having limited skills. According to the survey of Human Development Index, Indonesia stand is position of 113 from 188 countries in the World, and in the order of 5 from 11 ASEAN countries, one level above Philippine and one level below Thailand also two level below Brunei Darussalam [1]. The other data reveals that, in Indonesia, the level of breaking school continuity is still high based on the datasets of Badan Penelitian dan Pengembangan Kementerian Pendidikan dan Kebudayaan, stated that there are $21.92 \%$ Elementary graduates that do not continue to Junior High, 2.18\% Junior High graduate that do not continue to Senior High [2].

The research of Yuliwulandana, stated that "low capacity of college is in the amount of $12.6 \%$, most of them around $88.4 \%$ student enter the working world without life skills" [3]. So, the teenager in the productive-working age should have more life skills in order to compete and go through the real daily life demand and challenges. That statement is supported by Gould and Carson, statement that is said that "these days, youth generation is facing some challenges and in order to success as an adult in the very competitive and changeable global economic they should have learn more skills and developing life skills [4]." Citing Hodge and Danish statement in Cronin and Allen, that stated "life skill is defined as a skill that is needed to face the demand and challenge of daily life [5]." Life skill can also cover the physical aspect, for example healthy dietary habit, behaviour for example determining goals, or cognitive aspect for example self-talk [6].

The Cronin and Allen see life skills as behaviour, cognitive, interpersonal, or intrapersonal competence that can be learned, developed, and fixed [5]. Life skills include teamwork, goal setting, interpersonal communication, and leadership. These life skills can be applied in every aspect of every person life (example, school assignment, part-time work, friendship, sports). Next, The World Health Organization has suggested that the kind of life skills is important to prepare future youths and make sure their healthy development [7]. Then, Department of Mental Health has identified five basic life skills that is relevant in every culture, they are: decision-making and problem-solving; creative and critical thinking; communication and interpersonal skill; selfawareness and empathy; emotion and depression control [7].

The research of Jegannathan et al., reveals that developing life skills in school can increase the health of youth mental health [8]. The Hardcastle et al. conduct a research to high performance athlete toward youth sports programs that can develop life skills, the results find that the program is success enough to develop behaviour and adaptive motive including the better involvement in training and adopting the management skill and time schedule in the context out from sport such as house work and academic study [6]. The same as Larson research reveals that "youth generation develop their life skills through extracurricular such as music, drama, and 
sports also those extracurricular become more important in the $21^{\text {st }}$ century [9]." Same as Kendellen et al., statement that "many researcher has highlighted the intentional approach for developing youths life skills [10]."

Sports have been suggested as the ideal environment for developing life skills, because sport is one of the recreation activities that are most popular for youth generation. Cited from Cronin and Allen that said "some research shows that through sport, the youth has developed teamwork, determining goals, time management, emotional skills, communication, social skills, leadership, problem-solving and decisionmaking" [5]. The minimum research of sport extracurricular impact to the student life skills in Indonesia interest the researcher to study deeper related to the student life skills especially senior high school. Therefore, the researcher is going to conduct research with life skills as the theme in the scope sport education about how great is the sport extracurricular to the development of senior high school student's life skills. By this research, it is expected to increase the development of student's positive life skills. It is expected that volleyball extracurricular that integrated the eight-life skills component can also implemented in the physical exercise learning process by the school's teacher. Furthermore, this program is expected to be applied in outside school such as learning courses or sport club.

The research problems that will be answered through this research are: (1) Are there any difference in senior high school students' life skills development through volleyball extracurricular between the given treatment and not? (2) Are there any difference in senior high school students' life skills development through volleyball extracurricular between the given treatments to the students that are not joining the extracurricular? (3) Are there any difference in senior high school students' life skills development through volleyball extracurricular between the not-given treatments to the students that are not joining the extracurricular? (4) How is the development of life skills to sport students that are given treatment volleyball extracurricular?

\section{RESEARCH METHOD}

The research of the method was experiment research with the design of quasi-experimental. The form of the research used The Matching-Only Pretest-Posttest Control Group Design [11].

This study involved grade 10 and 11 High School students with the number of participants of 67 students that was divided into three groups. Group A with 27 students consists of 18 males, nine females. Group B with the number of 23 students consists of 16 males and seven females. Group $\mathrm{C}$ with the number of 17 students consists of seven males and 10 females. The sample collection technique was done by purposive. Purposive sampling used as sample determining technique with some consideration, in other word, based on the previous knowledge from the population and specific goal of the study, the researcher used personal judgment to choose the sample.

The instrument that was used to measure students life skills was questionnaire of Life Skills Scale for Sport (LSSS) which was developed by Cronin and Allen [5]. Questionnaire LSSS was developed for the youth participant of the age around $11-21$ years old. The questionnaire LSSS were contained eight main life skills consisted of 47 questions essay, with the scale of Likert in the range of 5 points from 1 (not at all) until 5 (very much). Before using the instrument, the researcher did validity and reliability test using IBM SPSS software version 23 . With the validity result used $\mathrm{r}$ calculated value in the comparison to $\mathrm{r}$ table, the result was $\mathrm{r}$ calculated $>$ r table (0.355). It was also by the reliability test used alpha Cronbach's value, the result was $\alpha=0.974$ which meant reliable. The data tabulation stage in this study used quantitative with descriptive and inferential statistics. The data tabulation is in the form of tabulation used Microsoft Excel 2013 program, then for the data analysis used descriptive statistic with the help of IBM SPSS software version 23. Statistic precondition test covered normality test and homogeneity used SPSS program version 23. In order to addressed the research problem in this study researcher made the hypothesis test in inferential statistic way used t-test that was independent sample t-test.

\section{RESULT AND DISCUSSION}

From the research that is already done, it is obtained the data for each group before the treatment (pre-test) and after the treatment (post-test) that is shown in Table 1.

TABLE I. DESCRIPTIVE STATISTIC OF THE RESEARCH RESULT

\begin{tabular}{|c|c|c|c|c|c|c|}
\hline \multirow{2}{*}{\multicolumn{2}{|c|}{$\begin{array}{l}\text { Research } \\
\text { Groups }\end{array}$}} & \multicolumn{5}{|c|}{ The Result of Statistic Descriptive } \\
\hline & & \multirow{2}{*}{$\begin{array}{l}\begin{array}{c}\text { Number } \\
\text { of } \\
\text { students }\end{array} \\
27\end{array}$} & \multirow{2}{*}{$\begin{array}{c}\begin{array}{c}\text { Total of } \\
\text { students } \\
\text { answer }\end{array} \\
4324 \\
\end{array}$} & \multirow{2}{*}{$\begin{array}{l}\text { Average } \\
160.15 \\
\end{array}$} & \multirow{2}{*}{$\begin{array}{l}\text { Standard } \\
\text { Deviation }\end{array}$} & \multirow{2}{*}{$\begin{array}{l}\text { Variances } \\
57.208\end{array}$} \\
\hline \multirow{2}{*}{ A } & Pre & & & & & \\
\hline & Post & 27 & 5318 & 196.96 & 13.12 & 172.037 \\
\hline \multirow{2}{*}{ B } & Pre & 23 & 4015 & 174.57 & 13.34 & 178.075 \\
\hline & Post & 23 & 4104 & 178.43 & 13.52 & 182.893 \\
\hline \multirow{2}{*}{$\mathrm{C}$} & Pre & 17 & 2435 & 143.24 & 25.50 & 650.066 \\
\hline & Post & 17 & 2551 & 150.06 & 20.50 & 420.184 \\
\hline
\end{tabular}

Based on Table 1 it is known that the students in group A are 27 with the average pre-test number of 160.15 and the average post-test number of 196.96. The Standard deviation of group $\mathrm{A}$ is in the number of 7.56 and 13.12. The students in group B are 23 with the average pre-test and post-test number of 174.57 and 178.43. The standard deviation of group B is in the number of 13.34 and 13.52. Then the group $C$ are 17 students, with the pre-test and post-test average number of 143.24 and 150.06. The standard deviation of group $C$ is in the number of 25.50 and 20.50 .

The percentage of life skills development in group (A) that consist of eight life skills components are explained in Figure 1 that shown all the life skills component reveals the increase that has the meaning there is development of life skills in SHS students that join the volleyball extracurricular which has the integration of life skills component toward positive impact. 


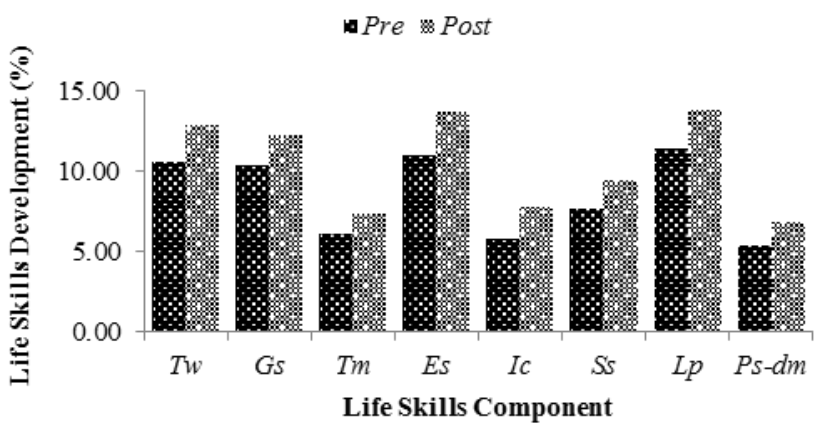

Fig. 1. The percentage of life skills development group A. (Tw) Teamwork; (Gs) Goal Setting; (Tm) Time Management; (Es) Emotional skills; (Ic) Interpersonal communication; (Ss) Social skills; (Lp) Leadership; (Ps-dm) Problem solving and decision making.

Each of the life skills component before and after given treatment has significance different. Student's Teamwork increasing to $2.3 \%$. This means that by joining volleyball extracurricular that is integrated to life skills component is increasing. It is also for the other life skills component, each of them are increasing such as goal setting, time management, emotional skill, interpersonal communication, social skill, leadership, and problem-solving and decision-making in the amount of $1.90 \% ; 1.20 \% ; 2.60 \% ; 2.00 \% ; 1.80 \% ; 2.40 \%$; and $1.50 \%$. The highest percentage of life skills development is in the Emotional skills, this means that the students' emotional skill that joins the volleyball extracurricular with given treatment is better than the not-given treatment. The same result has been stated by Brunelle et al. that said sport can developed character and values when combined with the Life Skills program and chance to be involved in the experience [12]. The skills to manage emotion by the students in sports are also important, moreover on the competitive sports such as volleyball. This statement is stated by Michael Gove in Cope et al. that said "football and other competitive team games as the 'better' games for building character" [13].

Overall, the percentage of life skill development in each group is explained by Figure 2, shows that there is difference in life skills between the students that join sports extracurricular with treatment; without treatment and not joining the sport extracurricular. The difference between the students that join extracurricular that is given treatment to the not-given treatment to the not joining sports has significant meaning. For example, the difference in Teamwork group $\mathrm{A}$ and $\mathrm{C}$ is in the number of $2.86 \%$, then in is revealed that the highest difference is Goal Setting component in the amount of 3.05\%. The difference can also found in group A and B that joins the sport extracurricular but one of them is not-given treatment, the biggest difference can be seen in the Goal Setting component in the amount of $1.44 \%$. Then between the student group that is not-given treatment to the student that is not joining the sport extracurricular also have a difference for example in Emotional Skills component in the number of $2.20 \%$ followed by Teamwork (1.85\%) and Leadership (1.80\%).

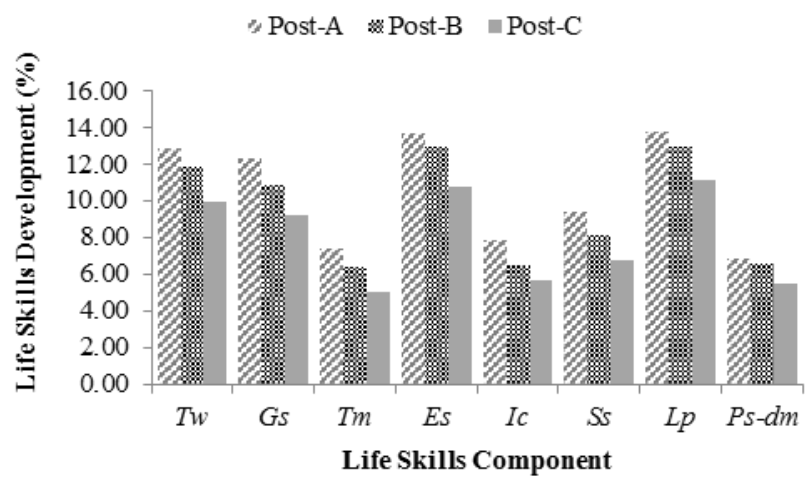

Fig. 2. The percentage of life skills development each group. (Tw) Teamwork; (Gs) Goal Setting; (Tm) Time Management; (Es) Emotional skills; (Ic) Interpersonal communication; (Ss) Social skills; (Lp) Leadership (Ps-dm) Problem solving and decision making.

Null hypothesis in this research is $\mathrm{H}_{01}$ : there is no difference between development average value of group A life skills (the volleyball extracurricular that is given treatment) to the average of group B (the volleyball extracurricular that is not-given treatment); $\mathrm{H}_{02}$ : there is no difference of the average value of life skills development in group A (the volleyball extracurricular that is not-given treatment) to the average value of group $\mathrm{C}$ (the group that is not joining sports extracurricular and not-given treatment); $\mathrm{H}_{03}$ : there is no difference in the life skills development in group B (the volleyball extracurricular that is not-given treatment) to the average value of group $\mathrm{C}$ (the group that is not joining sports extracurricular and not-given treatment) $\mathrm{H}_{04}$ : there is no difference in the pre-test average value to the post-test average value life skills development in group A (the volleyball extracurricular that is given treatment). The null hypothesis is analysed in inferential way by independent sample t test that is explained in Table 2.

TABLE II. RESUlT RECAPITULATION OF INDEPENDENT SAMPLE T TEST

\begin{tabular}{|c|c|c|c|c|}
\hline \multirow{2}{*}{$\begin{array}{c}\text { Post- } \\
\text { test }\end{array}$} & \multicolumn{4}{|c|}{ t-test for Equality of Means } \\
\cline { 2 - 5 } & $\begin{array}{c}\boldsymbol{t} \\
\text { counts }\end{array}$ & $\boldsymbol{d f}$ & $\begin{array}{c}\text { Sig. (2- } \\
\text { tailed) }\end{array}$ & $\begin{array}{c}\text { Mean } \\
\text { Difference }\end{array}$ \\
\hline $\mathrm{A}-\mathrm{B}$ & 4.908 & 48 & 0.000 & 18.53 \\
\hline $\mathrm{A}-\mathrm{C}$ & 9.279 & 42 & 0.000 & 46.90 \\
\hline $\mathrm{B}-\mathrm{C}$ & 5.276 & 38 & 0.000 & 28.38 \\
\hline
\end{tabular}

Based on Table 2, it can be seen that the results of the t-test for Equality of Means show the value of $t$ counts $A-B=4,908$ with Sig. $(2$-tailed $)=0.000$, and t table value $=2.011$. Because of $t$ counts $>t$ table, thus, hypothesis null is rejected, it means that there are differences of the development of high school students' life skills through volleyball extracurricular activities which are treated and those who are not. Both the average posttest values of group A and group B differ significantly with the difference of Mean Difference about $=18.53$. This is because students who take extracurricular activities that are given treatment there are programs that are integrated with aspects of life skills development. The treatment referred to here is volleyball sports extracurricular activities that already have a program in which there is a relationship between sports participation and the development of life skills. The results are found that suitable with the statements of Camiré et al. [14] 
which state that exercise can be used as a tool to improve the life skills and teenagers' positive development. Students who participate in extracurricular sports programs can improve their sports skills, while at the same time, the entry of Life Skills training in sports practice can be as an effective model in learning life skills [15].

Then the value of $\mathrm{t}$ counts $\mathrm{A}-\mathrm{C}=9.279$ with Sig. (2-tailed) $=0.000$, and $\mathrm{t}$ table value $=2.018$. Because $\mathrm{t}$ count $>\mathrm{t}$ table, so hypothesis null is rejected, it means there are differences of the development of high school students' life skills through volleyball extracurricular activities that are treated and those who are not. Both average posttest values of group A and group C differ significantly with the difference of Mean Difference about $=46.90$. The development of students' life skills who take part in the extracurricular activities of volleyball sports that are treated have gotten better results rather than the students who do not take part in volleyball sports extracurricular activities. This result has a big gain between students who take volleyball sports extracurricular activities that are treated and students who take volleyball extracurricular activities without treatment. Therefore, the extracurricular activities of volleyball sports have big impact to the development of students' life skills.

Students' life skills will have improvement if the students are provided the integration of extracurricular activities and life skills. This result is supported by the statement of Papacharisis et al. [15] that said a sports extracurricular program that integrates with the Life Skills is effective to develop the skills of students who take part in this program. Many skills learned in sports can be transferable to other domains of life, so Life Skills that have been developed through sports will be implemented in everyday life. These skills include the ability to do things under pressure, solve problems, meet deadlines or challenges, set goals, communicate, handle successes and failures, work with teams in a system, and receive feedback and benefits [15].

The value of $\mathrm{t}$ counts $\mathrm{B}-\mathrm{C}=5.276$ with Sig. (2-tailed) $=$ 0.000 , and table value $=2.024$. Because $t$ count $>\mathrm{t}$ table, so that hypothesis null is rejected, this means there are differences in the development of high school students' life skills through volleyball extracurricular activities that are not treated with those who are not. Both average of posttest values of group B and group $\mathrm{C}$ differ significantly with the difference of Mean Difference $=28.38$. These results indicate that students who take volleyball extracurricular activities without being treated have better development than students who did not take extracurricular activities at all. The results shown that it is very important for volleyball sports extracurricular activities to improve the development of students' life skills. Although extracurricular activities are followed by students without treatment, students have the development of life skills as well. This is due to the additional time used by students who take volleyball sports extracurricular activities in developing their skills outside of sports classes time in class. Unlike students who do not take extracurricular activities who only take part in volleyball sports during physical education and sports classes in class.
Students who take volleyball extracurricular activities without treatment at least take their free time to develop positive attitudes and avoid the waste time that will lead to delinquency or negative activities carried out by teenagers. This is in line with Gould's explanation in Winarni [16], that youth participation in sports activities reduces crime behavior than teenagers who do not participate in sports activities. Participating in sports activities keeps students away from activities on the streets and away from social problems. Social bond are characterized by students who participate in sports activities, namely developing a sense of recognition of others, especially in people who are dominant and pro-social values [16].

Knowing the development of life skills of students of volleyball sports extracurricular groups who are given treatment can be seen in Table 3.

TABLE III. ThE GROUP A RESUlTS OF INDEPENDENT SAMPLE T TEST PRE-TEST AND POST-TEST

\begin{tabular}{|c|c|c|c|c|}
\hline \multirow{2}{*}{$\begin{array}{c}\text { Pretest and } \\
\text { Posttest }\end{array}$} & \multicolumn{4}{|c|}{ t-test for Equality of Means } \\
\cline { 2 - 5 } & t count & $\boldsymbol{d f}$ & $\begin{array}{c}\text { Sig. (2- } \\
\text { tailed) }\end{array}$ & $\begin{array}{c}\text { Mean } \\
\text { Difference }\end{array}$ \\
\hline $\begin{array}{l}\text { Equal variances } \\
\text { assumed }\end{array}$ & 12.634 & 52 & 0.000 & 36,81 \\
\hline
\end{tabular}

Based on Table 3, it can be seen that the results of the t-test for Equality of Means shows the value of $t=12.634$ with Sig. $(2$-tailed $)=0.000$, and table value $=2.007$. Because of $t$ counts $>\mathrm{t}$ table, so that $\mathrm{H} 0$ is rejected, it is defined as there is a difference between the average pretest score and the average posttest value of life skills development in group A (extracurricular volleyball sport group that was not treated. Both groups average pretest and posttest scores A differs significantly from the difference of Mean Difference $=36.81$ Life skills for students who take extracurricular activities are very useful for them after plunging and living in the community, because life skills are skills or life skills that will be used to survive their problems. Life skills are also a form of positive development for high school students as youth. These life skills can be integrated into volleyball sports extracurricular activities at school. This statement is supported by Danish et al. who stated that "Sports is one activity that can be to improve positive development for young people" [17]. The final value of the experience of participating in sports activities lies in the application of the principles that have been learned and then transferred to other fields. Attitudes and behaviors that can be transferred into other fields can be the application of Life Skills in life.

Sports extracurricular programs integrated with Life Skills are adjusted with the knowledge and skills needed to overcome the complex realities of life. Thus, relating the increasing life skills of students, it will improve their skills in goal setting, problem solving, and positive thinking skills. Examples of life skills are like teamwork, goal setting, interpersonal communication, and leadership which be expressed by Papacharisis et al. [15]. Organized activities as contexts are very important, it can encourage positive development of students [18]. This means that sports activities that have an organized program and be able to continuously encourage 
positive development of students, thus, it will hone the life skills of students. Programmed activities will make students become more organized, more disciplined and respectful of time. This will develop students' life skills or time management's life skills.

The gain scores result of groups A - B and A - C can be seen in Table 4. It can be seen that the results of the t-test for Equality of Means show Gain score of A - B with the value of $t$ count $=13.940$ with Sig. $(2$-tailed $)=0.000$, and $t$ table value $=$ 2.011. Because $t$ count $>\mathrm{t}$ table, so $\mathrm{H} 0$ is rejected, it means there is a difference between the average gain value of group A and the average gain value of group B development of life skills. Both average gain values of groups A and group B differ significantly with the difference of Mean Difference about $=$ 27.80. Then Gain Score A - C with the value of $\mathrm{t}$ count $=9.855$ with Sig. $(2$-tailed $)=0.000$, and t table value $=2.018$. Because of $\mathrm{t}$ count $>\mathrm{t}$ table, then $\mathrm{H} 0$ is rejected, it defines that there is a difference between the average gain value of group $\mathrm{A}$ and the average gain value of group $\mathrm{C}$ development of life skills. Both average gain values of groups $\mathrm{A}$ and group $\mathrm{C}$ differ significantly with the difference of Mean Difference about $=$ 24.84 .

TABLE IV. The GAIN SCORE RESUlt OF INDEPENDENT SAMPLE T TEST

\begin{tabular}{|l|l|l|l|l|}
\hline \multirow{2}{*}{ Gain Score } & \multicolumn{4}{|c|}{ t-test for Equality of Means } \\
\cline { 2 - 5 } & t count & $\boldsymbol{d f}$ & $\begin{array}{c}\text { Sig. (2- } \\
\text { tailed) }\end{array}$ & $\begin{array}{c}\text { Mean } \\
\text { Difference }\end{array}$ \\
\hline $\mathrm{A}-\mathrm{B}$ & 13.940 & 48 & 0.000 & 27.80 \\
\hline $\mathrm{A}-\mathrm{C}$ & 9.855 & 42 & 0.000 & 24.84 \\
\hline
\end{tabular}

Overall, it was decided that there were significant differences of the impact of volleyball sports extracurricular activities that were treated with those who were not on the development of the life skills of high school students. The statement above is supported by Bakoban and Aljarallah who states that "the various experiences gained from participating in extracurricular activities are able to have a positive impact on students' emotional, intellectual, social and interpersonal development" [19]. Further stated that through interacting and working with others students can learn to negotiate, communicate, manage conflict and lead. Not only that participating in outdoor activities such as extracurricular activities can help students to understand the importance of critical thinking skills, and time management.

Considering that the life skills integration program into extracurricular activities is only eight meeting with 90 minute per sessions, the results are quite effective to develop students' life skills and this is suitable with the findings of the implementation of the 'GOAL' program in the school environment [20], because the 'GOAL' program was carried out with 10 hours, 10 sessions. Therefore, life skills training integrated into volleyball sports extracurricular activities can improve the development of high school students' life skills. The integration of life skills training into sports practices can serve as an effective model for developing life skills. The statement above is supported by Papacharisis et al. which states that "athletes who participate in the integration program of life skills training into sports programs can improve their sports skills. At the same time, integrated life skills training into sports practice can serve as an effective model for learning and developing life skills" [15]. Dealing with the development of life skills such as teamwork, goal setting, time management, emotional skills, interpersonal communication, social skills, leadership, problem solving and decision making, students have a good opportunity to become better individuals, better athletes, and members a more caring and productive society.

\section{CONCLUSION}

The development of students' life skills participating in volleyball sports extracurricular activities integrated with life skill components is better than the development of life skills of high school students who take volleyball extracurricular activities without the integration of life skill components in the program. The development of students' life skills can be implemented in the daily life of students, hence it can be used to deal with the needs and challenges of their lives in accordance with the benefits of life skills. This result was obtained after eight meetings that shows very good results, especially if the volleyball sports extracurricular program integrated with the life skill component was carried out continuously, allowing the results to be far better than the results achieved when it was carried out only eight times. So that the existence of volleyball sports extracurricular activities integrated with eight components of life skills will increase the development of students' life skills in a positive direction. Thus, it can be used as a program for volleyball extracurricular sports teachers to carry out extracurricular activities on an ongoing basis. This program does not only enhance or develops students 'physical skills in volleyball, but also it develops students' life skills which will be very useful for them in their experiences in society's life.

\section{REFERENCES}

[1] Human Development Index, Human Development Report 2016 Human Development for Everyone. New York: United Nations Development Programme, 2016.

[2] Badan Penelitian dan Pengembangan Kementerian Pendidikan dan Kebudayaan, "Ikhtisar Data Pendidikan Tahun 2016/2017," Jakarta, 2017.

[3] N. Yuliwulandana, "Pengembangan Muatan Kecapakan Hidup (Life Skills) pada Pembelajaran di Sekolah," Tarb. J. Ilm. Pendidik., vol. 12 no. 2, pp. 191-206, 2015.

[4] D. Gould and S. Carson, "The relationship between perceived coaching behaviors and developmental benefits of high school sports participation,” Hell. J. Psychol., vol. 7, no. 3, pp. 298-314, 2010.

[5] L. D. Cronin and J. Allen, "Development and initial validation of the Life Skills Scale for Sport," Psychol. Sport Exerc., vol. 28, pp. 105-119, 2017.

[6] S.J. Hardcastle, M. Tye, R. Glassey, and M.S. Hagger, "Exploring the perceived effectiveness of a life skills development program for highperformance athletes," Psychol. Sport Exerc., vol. 16, no. P3, pp. 139149, 2015.

[7] World Health Organization, "Partners in life skills education: conclusions from a United Nations Inter-Agency Meeting," Partners in life skills education: Conclusions for a United Nations inter-agency meeting, $1999 . \quad$ [Online]. Rerieved from: http://www.who.int/mental_health/media/en/30.pdf. [Accessed: 20-Jan2018]. 
[8] B. Jegannathan, K. Dahlblom and G. Kullgren, "Outcome of a schoolbased intervention to promote life-skills among young people in Cambodia,” Asian J. Psychiatr., vol. 9, pp. 78-84, 2014.

[9] R.W. Larson, "Toward a psychology of positive youth development," Am. Psychol., vol. 55, no. I, pp. 170-183, 2000.

[10] K. Kendellen, M. Camiré, C.N. Bean, T. Forneris and J. Thompson, "Integrating life skills into Golf Canada's youth programs: Insights into a successful research to practice partnership," J. Sport Psychol. Action, pp. 1-13, 2016

[11] J.R. Fraenkel, N.E. Wallen, and H.H. Hyun, How to Design and Evaluate Research in Education, 8th ed. New York: McGraw-Hill, 2012.

[12] J. Brunelle, S.J. Danish and T. Forneris, "The impact of a sport-based life skill program on adolescent prosocial values," Appl. Dev. Sci., vol. 11, no. 1, pp. 43-55, 2007.

[13] E. Cope, R. Bailey, D. Parnell, and A. Nicholls, "Football, sport and the development of young people's life skills," Sport Soc., vol. 0437, no. July, pp. 1-14, 2016.

[14] M. Camiré, P. Trudel and T. Forneris, "High school athletes' perspectives on support, communication, negotiation and life skill development," Qual. Res. Sport. Exerc., vol. 1, no. 1, pp. 72-88, 2009.
[15] V. Papacharisis, M. Goudas, S. J. Danish, and Y. Theodorakis, "The effectiveness of teaching a life skills program in a sport context," J. Appl. Sport Psychol., vol. 17, no. 3, pp. 247-254, 2005.

[16] S. Winarni, "Pengembangan Karakter Dalam Olahraga Dan Pendidikan Jasmani," J. Cakrawala Pendidik., vol. 2, no. XXX, pp. 124-139, 2011.

[17] S.J. Danish, T. Forneris and I. Wallace, "Sport-Based Life Skills Programming in the Schools," J. Appl. Sch. Psychol., vol. 21, no. 2, pp. 41-62, 2005.

[18] J. Fraser-thomas and J. Côté, “Understanding Adolescents' Positive and Negative Developmental Experiences in Sport Understanding Adolescents' Positive and Negative Developmental Experiences in Sport," Sport Psychol., vol. 23, pp. 3-23, 2009.

[19] R.A. Bakoban and S. A. Aljarallah, "Extracurricular activities and their effect on the students grade point average: Statistical study," Educ. Res. Rev., vol. 10, no. 20, pp. 2737-2744, 2015.

[20] S.J. Danish and V.C. Nellen, "New roles for sport psychologists: Teaching life skills through sport to at-risk youth," Quest, vol. 49, no. 1, pp. 100-113, 1997. 